\title{
MAMMOGRAM: DETECTION OF MALIGN TUMORS IN WOMEN FROM SANTA CATARINA AND BRAZIL
}

\author{
Luciana Martins da Rosaํ, Luciana da Silva², Vera Radunz³, María Angélica Arzuaga
}

\begin{abstract}
${ }^{1}$ Ph.D. in Nursing. Professor, Departamento de Enfermagem, Programa de Pós-Graduação em Gestão do Cuidado de Enfermagem, Universidade Federal de Santa Catarina (UFSC). Florianópolis, Santa Catarina, Brazil. E-mail: luciana.m.rosa@ufsc.br

${ }^{2}$ M.Sc. in Public Health. Coordenadora de Saúde Bucal da Atenção Básica, city of Urubici. Urubici, Santa Catarina, Brazil. E-mail: lubertan@hotmail.com

${ }^{3}$ Ph.D. in Nursing. Professor, Departamento de Enfermagem, UFSC. Florianópolis, Santa Catarina, Brazil. E-mail: vera.radunz@ufsc.br

${ }^{4}$ Ph.D. in Nursing. Professor, Facultad de Enfermería, Unversidad de Antioquia. Medellín, Antioquia, Colombia. E-mail: maria.arzuaga@ udea.edu.co
\end{abstract}

\begin{abstract}
The purpose is to analyze the incidence rate of malignant neoplastic lesion by detection type and the proportional distribution of mammograms in women between 40 and 69 years of age from the State of Santa Catarina and from Brazil. This is a descriptive observational study of data from the Information Technology Department of the Unified Health System between 2009 and 2012 and the Brazilian Institute of Geography and Statistics. The greatest mammography coverage was in the group from 45 to 49 years, $22.2 \%$ in Brazilians and $23.1 \%$ in women from Santa Catarina. The greatest proportional distribution was 89.2\% in Brazilian women between 40 and 44 years and women from Santa Catarina between 50 and 54 years. The incidence rates of malignant neoplastic breast lesion diagnosed by imaging increased in Brazil and Santa Catarina. In Brazil, in 2012, the highest detection was by palpation and, in Santa Catarina, by imaging. In conclusion, the screening is below the recommended, the higher proportional distributions of mammograms permitted a larger number of diagnoses of malignant neoplastic lesions and the application of mammograms as from the age of 40 years contributed to the diagnosis of breast cancer between the ages of 40 and 49 years.
\end{abstract}

DESCRIPTORS: Mammography. Breast neoplasms. Nursing. Oncology.

\section{RASTREAMENTO MAMOGRÁFICO: DETECÇÃO DE LESÕES NEOPLÁSICAS MALIGNAS EM MULHERES DE SANTA CATARINA E DO BRASIL}

RESUMO: Objetivou-se analisar as taxas de incidência de lesão neoplásica maligna, por forma de detecção e distribuição proporcional das mamografias em mulheres de 40 a 69 anos do Estado de Santa Catarina e do Brasil. Realizou-se estudo observacional descritivo em dados obtidos no Departamento de Informática do Sistema Único de Saúde entre 2009 e 2012 e no Instituto Brasileiro de Geografia e Estatística. No Brasil e em Santa Catarina a maior cobertura de mamografias de mulheres dos 45 aos 49 anos equivaleram a 22,2\% e 23,1\%. A maior distribuição proporcional foi de $89,2 \%$ nas brasileiras de 40 a 44 anos e nas de 50 a 54 anos em Santa Catarina. As taxas de incidência de lesão neoplásica maligna de mama diagnosticada por imagem elevaram-se no Brasil e em Santa Catarina. Em 2012, no Brasil a maior detecção ocorreu por meio da palpação, enquanto em Santa Catarina ocorreu por imagem. Concluiu-se que o rastreamento está abaixo do recomendado, que as maiores distribuições proporcionais de mamografias permitiram maior número de diagnósticos de lesões neoplásicas malignas e que a realização da mamografia a partir dos 40 anos contribuiu para o diagnóstico do câncer de mama entre a faixa dos 40 e 49 anos.

DESCRITORES: Mamografia. Neoplasias das mamas. Enfermagem. Oncologia.

\section{CRIBADO MAMOGRÁFICO: DETECCIÓN DE LESIONES NEOPLÁSICAS MALIGNAS EN MUJERES DE SANTA CATARINA Y BRASIL}

RESUMEN: El objetivo fue analizar las tasas de incidencia de lesión neoplásica maligna según tipo de detección y distribución proporcional de mamografías en mujeres de 40 a 69 años del Estado de Santa Catarina y de Brasil. Se trata de un estudio observacional descriptivo fundamentado en datos del Departamento de Tecnología de la Información del Sistema Único de Salud entre 2009 y 2012 y del Instituto Brasileño de Geografía y Estadística. En Brasil y en Santa Catarina, la mayor cobertura de la mamografía en mujeres de 45 a 49 años fue de 22,2\% y 23,1\% respectivamente. La mayor distribución proporcional fue de $89,2 \%$ en las brasileñas de 40 a 44 años y de 50 a 54 años en Santa Catarina. Las tasas de incidencia de lesión neoplásica maligna de mama diagnosticada por imagen se elevaron en el Brasil y Santa Catarina. En 2012, en Brasil la mayor detección ocurrió por medio de la palpación y en Santa Catarina a través de imagen en 2012. Se concluye que el cribado mamográfico está por debajo del nivel recomendado. Mayores distribuciones proporcionales de mamografías permitieron mayor número de diagnósticos de lesiones neoplásicas malignas y finalmente, la realización de la mamografía a partir de los 40 años contribuyó para el diagnóstico de cáncer de mama entre la fase etaria de 40 a 49 años.

DESCRIPTORES: Mamografía. Neoplasias de la mama. Enfermería. Oncología. 


\section{INTRODUCTION}

Mammogram screening aims for the early detection of breast alterations and the reduction of the mortality rates caused by breast cancer. ${ }^{1}$ Concern with the detection and early start of breast cancer treatment is related to the magnitude of the disease, which is considered a public health problem in Brazil and around the world. The International Agency for Research on Cancer published that, in 2012, approximately 1.6 million new cases of the disease happened globally, 522 thousand deaths and, among these deaths, almost 17 thousand cases involved Brazilian women. ${ }^{2}$ For 2016, the Instituto Nacional do Câncer (INCA) has estimated that about 60 thousand new cases will occur in Brazil, two thousand of which in the state of Santa Catarina. ${ }^{3}$

According to the United States Preventive Services Task Force (USPSTF), the recommendations for breast cancer screening, mammogram screening every two years is more beneficial for women between 50 and 74 years of age, and that women between 40 and 49 years should make individual decisions about having a periodical mammogram or not, together with their physicians, taking into account the benefits and damages of this practice. ${ }^{4-5}$ Mammogram screening can reduce the risk of death by the disease by up to $20 \%$, corresponding to $15 \%$ for the population between 40 and 49 years, 14\% between 50 and 59 years and $38 \%$ for the population between 60 and 69 years. ${ }^{6}$

As opposed to the USPSTF, the Brazilian Society of Mastology (BSM) indicates that mammogram tests should start at the age of 40 years. The BSM argues that the American medical societies that take care of women with breast cancer harshly criticized the USPSTF recommendations. The first criticism refers to assertion that having a mammogram reduces mortality rates in women between 40 and 49 years by only $15 \%$, established by the inclusion of a Canadian study entitled National Breast Service Screening, widely criticized because of errors in the method and quality of the mammogram. The second criticism involves the insufficient number of women included in the mammogram screening and which led to the establishment of the recommendation published. In addition, it reaffirms that most medical societies, including the American Cancer Society, American College of Radiology, National Comprehensive Cancer Network, National Cancer Institute, the BSM and the Brazilian College of Ra- diology recommend annual mammogram screening as from the age of 40 years. ${ }^{1}$

The INCA recommends the two-yearly mammogram for women between 50 and 69 years of age, equal to the USPSTF recommendation. For women with a high risk of breast cancer, the institute recommends an annual clinical breast exam and mammogram as from the age of 35 years. ${ }^{7}$

In view of existing controversies, this study departs from the following research questions: how were the mammograms of women between 40 and 69 years of age distributed proportionally and what are the incidence rates of malignant neoplastic lesion (MNL) of the breast between the ages of 40 and 69 years per detection type in women in Santa Catarina and in Brazil in the period from 2009 till 2012? And how can these analyses guide the discussions on the best date to start mammogram screening?

The analysis proposed here can support the understanding of the importance of breast cancer screening per age range and how the population has adopted this practice, as well as the relation between having a mammogram and the detection of breast cancer in Brazil. It can also contributed for the health practice adopted in Brazil and in Santa Catarina to favor the early diagnosis of breast cancer. ${ }^{8}$

It is highlighted that Santa Catarina was included because it is one of the Brazilian states with the highest incidence rate of breast cancer cases and because that is the State the researchers are affiliated with.

Therefore, the objective in this study is to analyze the incidence rates of MNL per detection type and the proportional distribution of mammograms in women between 40 and 69 years of age in the State of Santa Catarina and in Brazil.

\section{METHOD}

This observational and descriptive spatial and temporal distribution study was developed based on the analysis of secondary data obtained in the official databases of the Departamento de Informática do Sistema Único de Saúde/Sistema de Informações do Câncer de Mama - DATASUS/SISMAMA ${ }^{9}$ and information collected from the Instituto Brasileiro de Geografia e Estatística (IBGE). ${ }^{10}$ The data were collected on March $18^{\text {th }} 2014$. The investigated excerpt was the period between 2009 and 2012 .

The final limit of the excerpt (the year 2012) was established, considering that SISMAMA needs 
some time to calculate all information from the national territory, that is, the inclusion of data after 2012, in view of the data collection for this study in March 2014, would include partial records of data for 2013 and 2014. 2009, the start date, was established because SISMAMA started working in that year.

The area studied was the Brazilian territory, which covers an area of 8,514,215.3 $\mathrm{km}^{2}$ and has an estimated population of 191,481,045 inhabitants, $97,348,809$ of whom are women. The other area analyzed was the State of Santa Catarina, located in the South of Brazil, with a territory of $95,703,487 \mathrm{~km}^{2}$ and an estimated population of 6,248,436 inhabitants. ${ }^{10}$

The study population consisted of women between 40 and 69 years of age from Santa Catarina and from Brazil. The study variables were: a) number of women between 40 and 44 years, between 45 and 49 years, between 50 and 54 years, between 55 and 59 years and between 60 and 69 years in Santa Catarina and in Brazil; ${ }^{10}$ b) number of mammograms done in Santa Catarina and Brazil per age range analyzed: between 40 and 44 years, from 45 till 49 years, from 50 till 54 years, from 55 till 59 years and from 60 till 69 years; ${ }^{9}$ ) number of new cases of MNL of the breast diagnosed by clinical breast exam (palpation), per age range analyzed and per year investigated; 9 d) number of new cases of MNL of the breast diagnosed by imaging per research year and age range analyzed; ${ }^{9} \mathrm{e}$ ) number of new cases of MNL of the breast diagnosed by histopathological test per age range analyzed and per research year. ${ }^{9}$

For the data collection, the tools available in DATASUS/SISMAMA ${ }^{9}$ were used, which produce worksheets with the crossing of the requested information. To obtain the number of women per age range, the data from the 2010 Census were used. ${ }^{10}$ With the collected data at hand, worksheets were elaborated in Microsoft Excel, through which calculations were elaborated for the descriptive analysis of the data (incidence rates and proportions). The calculations used are presented next and were based on the indicators for the breast cancer control actions. ${ }^{11}$

To study the spatial and temporal distribution of the mammograms done in Santa Catarina and in Brazil in the age ranges between 40 and 44 years, 45 and 49 years, 50 and 54 years, 55 and 59 years and 60 and 69 years between 2009 and 2012, first, the number of mammograms done in each age range and each year analyzed was calculated; then, it was multiplied by 100 and divided by the number of women per location and in each age range studied.

To analyze the temporal and spatial evolution of MNL cases of the breast, the incidence rates were calculated between 2009 and 2012 in Santa Catarina and in Brazil, according to the detection criteria: clinical breast exam (detection by palpation), mammogram (detection by imaging) and histopathological exam.

To calculate the rates for the cases confirmed by clinical breast exam (palpation) and imaging, the number of cases of MNL of the breast detected by clinical breast exam (palpation) and imaging in each year studied was surveyed; next, this number was divided by the reference population of women and multiplied by the constant of 100,000 women.

To calculate the incidence rate of MNL detected by histopathological test, the cases of MNL were surveyed between 2009 and 2012 in Santa Catarina and in Brazil and divided by the number of women in Brazil and in Santa Catarina in each age range studied (40-44 years, $45-49$ years, $50-54$ years, $55-59$ years, 60-69 years). Then, the result was multiplied by the constant of 100,000 women.

The populations of women in each age range, in Santa Catarina and in Brazil, used as denominators to calculate the incidence rates and the mammogram proportions referred to the annual population projections for the study period, published by the IBGE, 2010 Census. $^{10}$

\section{RESULTS}

According to the studies undertaken in the database of SISMAMA between 2009 and 2012, $8,960,659$ mammograms were accomplished in Brazil in women between 40 and 69 years of age, of which 426,217 were undertaken in the state of Santa Catarina. In Brazil, 22.2\% of these tests were applied to women between 45 and 49 years of age and, in Santa Catarina, the situation was similar, as most of these mammograms also involved women between 45 and 49 years of age (23.1\%).

Figure 1 shows the proportional distribution of women who underwent the mammogram in Brazil and in Santa Catarina per age range and per year investigated. 


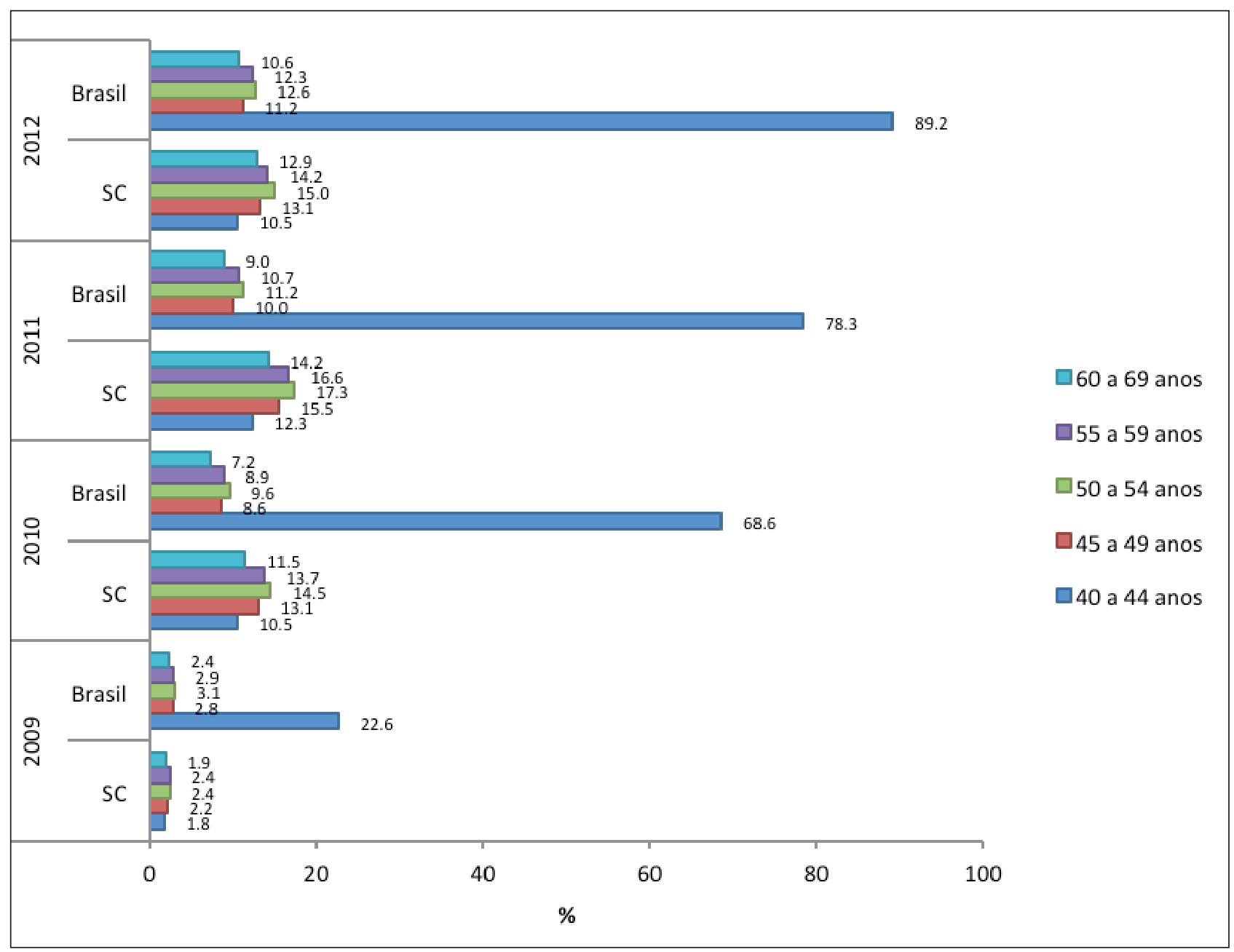

Figure 1 - Proportional distribution of mammograms per age range. Santa Catarina and Brazil, 2009-2012

In Brazil, it was verified that, in the years studied, women between 40 and 44 years presented the largest proportion of mammograms. In 2012, it was observed that almost $90 \%$ of the Brazilians between 40 and 44 years of age underwent a mammogram.

In Santa Catarina, the proportional distribution of the mammograms was balanced across the years studies and the age ranges analyzed. The age range from 50 till 54 years presented the highest test coverage rate, particularly in 2011 , when $17.3 \%$ of the women in Santa Catarina underwent a mammogram.

As regards the detection of breast cancer, between 2009 and 2012, 14,780 cases of MNL of the breast were detected by clinical exam in Brazil and 8,715 by imaging. In Santa Catarina, in the same period, 332 cases of MNL of the breast detected by clinical exam were confirmed and 287 cases detected by imaging.
Figure 2 shows that the incidence rates of MNL of the breast, diagnosed by imaging, showed a progressive and continuing increase in Santa Catarina and in Brazil between 2009 and 2012. The incident cases detected by palpation in Santa Catarina remained practically unchanged, while the cases detected by imaging increased progressively across the research period. In 2012, the detection rate by imaging was higher than the detection by palpation. In Brazil, the incidence rate of MNL of the breast detected by palpation was higher than the rates found in Santa Catarina between 2010 and 2011. In 2011, 2.1 new cases were detected per 100,000 women in Brazil and, in 2012, a drop to 18.3 cases was observed for every group of 100,000 women. In 2012, the detection rates by imaging in Santa Catarina and in Brazil were similar, corresponding to about $14 \%$. 


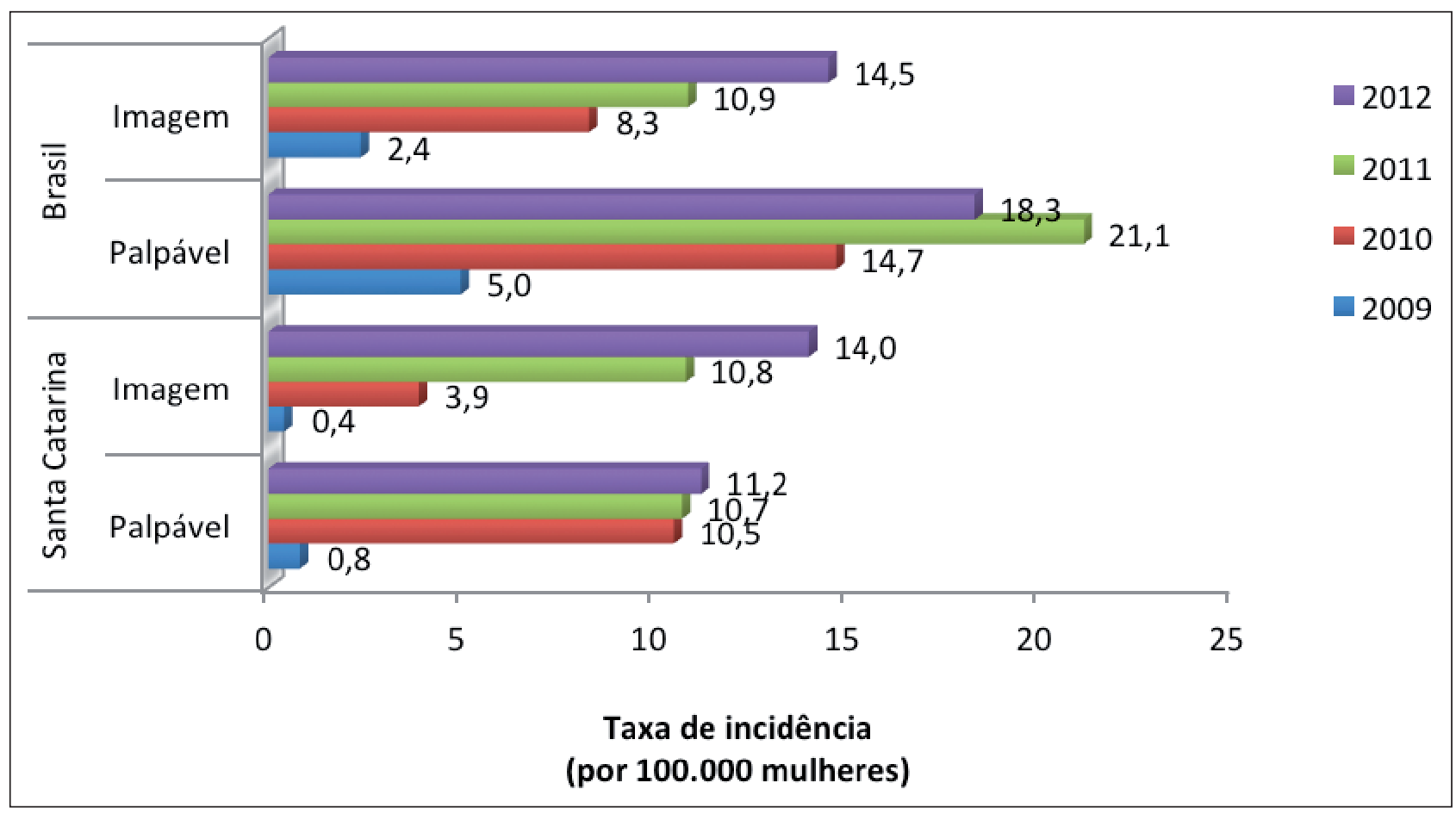

Figure 2 - Incidence rate of malignant neoplastic lesion of the breast, according to diagnostic type and year of study. Santa Catarina and Brazil, 2009-2012

The number of cases diagnosed by means of the histopathological test increased year by year between 2009 and 2012 in Brazil and in Santa Catarina. In Brazil, among women between 40 and 69 years of age, 22,215 cases of MNL of the breast were detected through the histopathological test while, in Santa Catarina, the number corresponded to 647 cases. As regards the age range, the women between 45 and 49 years of age concentrated the largest number of cases of MNL confirmed by the histopathological test across the years studied.

In Figure 3, it is observed that the incidence rates of MNL of the breast detected by means of the histopathological test demonstrated a relative increase across the study period in all age ranges analyzed in Santa Catarina and in Brazil. In Brazil, the women between 40 and 44 years presented the highest incidence rates. In 2011, the incidence rate amounted to 156.5 cases for every 100,000 women. In Santa Catarina, the incidence rate of MNL of the breast detected by the histopathological test was higher among women between 60 and 64 years in 2011 and 2012. In 2009 and 2010, the incidence rate was higher among women between 50 and 54 years. In 2012, the highest incidence rate for MNL of the breast was diagnosed by the histopathological test in Santa Catarina, corresponding to 41.2 cases per 100,000 women in Santa Catarina between 60 and 64 years of age.

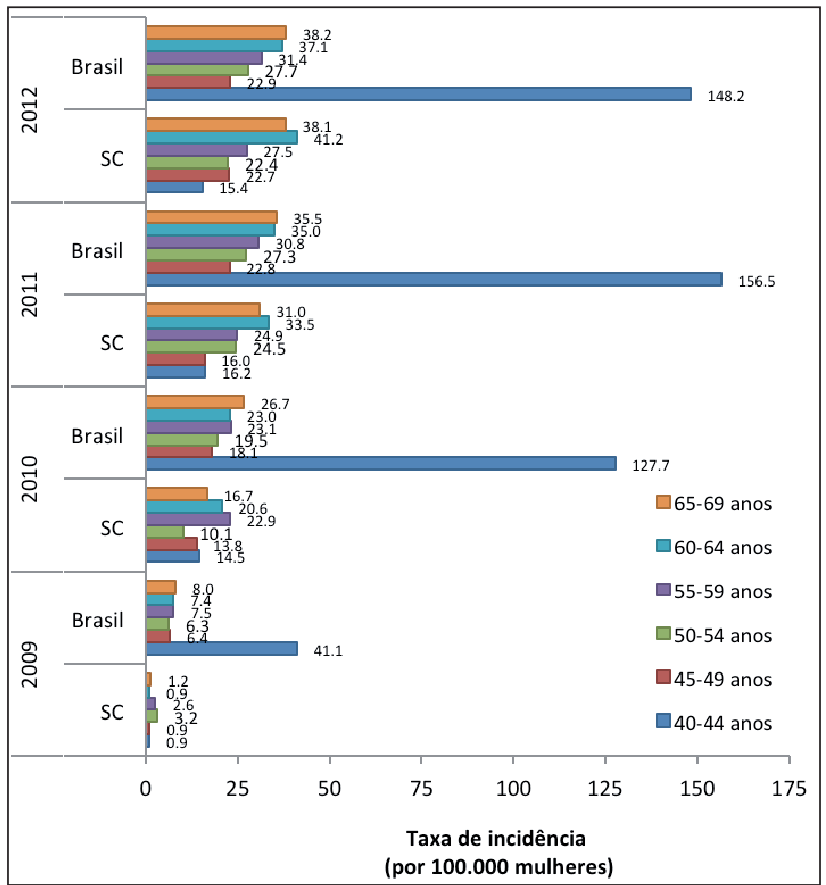

Figure 3 - Incidence rate of malignant neoplastic lesion of the breast detected by histopathological test, according to age range and year investigated. Santa Catarina and Brazil, 2009-2012

\section{DISCUSSION}

The number of mammograms done and the proportional distribution of the test per age range, 
per year investigated in this study, showed an increase in the number of mammograms taken by women in Brazil and in Santa Catarina. This change is associated with the increase in the number of breast cancer cases that have required cultural and political changes for cancer control in Brazil.

These results are similar to the findings in other studies that assessed the practice of mammograms in Brazil, including the South. They showed that, between 2003 and 2009, the number of women who underwent mammograms increased considerably, corresponding to $54.8 \%$ of the women over 25 years of age. In the South, the increase amounted to $15 \%$ and, between 2009 and 2010, the number of mammograms tripled. ${ }^{12-13}$

The greater proportional distribution of the mammograms appointed in this study is favorable; nevertheless, it is observed that the age range between 50 and 69 years, when the screening is most indicated, ${ }^{7}$ presented a mammogram coverage rate lower than in the range between 40 and 49 years. This finding can be a source of concern, as the women who are statistically at higher risk of breast cancer are not being screened according to the recommendations. This result is also similar to the prevalence of mammograms in Brazil, including the South between 2003 and 2008, and in another study developed in the city of Florianópolis. ${ }^{12,14}$

It is highlighted that the World Health Organization (WHO) recommends that $70 \%$ of the women between 50 and 69 years of age have a mammogram for the purpose of breast cancer screening. ${ }^{15}$ In view of the findings, it is clear that that is not the case in Brazil and in Santa Catarina, which can entail late diagnoses, advanced staging and low survival of the women affected by the disease.

The screening at regular intervals, by all women within the recommended age range, can reduce the mortality due to breast cancer by up to $30 \%$, and can also reduce the number of neoadjuvant treatments of the disease. ${ }^{16}$

Despite the controversies on the ideal age to start the practice of the mammogram, the increase in the number of tests in Brazilian women between 40 and 44 years shown in this study can be considered good evidence, as different studies suggest that mammogram screening for breast cancer should occur as form the age of 40 years. ${ }^{1,17-19}$

On the other hand, it should be highlighted that, although almost $80 \%$ of the Brazilian women between 40 and 44 years had a mammogram in 2011 and 2012, many of these women may have needed other tests to complement the diagnoses as, in this age range, it is common for women to still have dense breast tissue, suggesting the use of ultrasound imaging to support the early detection of breast cancer and the definition of more precise positive and negative diagnoses. ${ }^{19-21}$ For some women, however, the access to ultrasound imaging is difficult, and this condition extends the length of the diagnosis and, consequently, the onset of the breast cancer treatment. ${ }^{22}$

Among the women from Santa Catarina, an increase was also observed in the coverage of mammograms during the study period in all age ranges but, differently from the national context, it was observed that, between the ages of 50 and 59 years, screening rates were higher. Thus, one may say that the results reached in the State of Santa Catarina are closer to the USPSTF and INCA recommendations for screening. Nevertheless, the proportional distribution of the mammograms still remains inferior to WHO's recommendation.

Concerning the detection forms of breast cancer, the progressive and continuous growth of diagnostic imaging is highlighted in Brazil and in Santa Catarina between 2009 and 2012. In Brazil, however, the detection form by palpation still presents higher incidence rates than the detection rates by imaging between 2010 and 2012. It is emphasized that in Brazil as well as in Santa Catarina, the imaging detection rates need to rise with a view to permitting breast cancer diagnoses with a greater potential of cure and lower risks of relapse and premature death. The growth of diagnostic imaging is a good health indicator, as it is associated with the early detection, initial staging of the disease and higher survival rates. ${ }^{1}$

It was observed that the incidence rates of MNL of the breast detected by histopathological test were high in Brazil, mainly for the age range from 40 to 44 years between 2010 and 2012. This evidence emphasizes the need for mammogram screening in that age range, against the indication of the INCA and USPSTF. This finding adds up to the indications in other studies, which affirm the importance and need for regular mammogram screening as from the age of 40 years. . $-6,17-20^{-1}$

In Santa Catarina, the incidence rate of MNL of the breast detected by histopathological test differed from the findings in Brazil, as women between 50 and 69 years were the group that most received the breast cancer diagnosis based on a histopathological exam. In Brazil, on the other hand, the highest rates were found between the ages of 40 and 44 years. These findings are associated with the greater mam- 
mogram coverage in Santa Catarina and in Brazil in the respective age ranges (comparison between Figures 1 and 3), which favored the diagnosis, highlighting the importance of screening.

The reality discussed is also appointed in another study of the SISMAMA records in 2010, which shows that the increase in the number of mammograms in all age ranges contributes to the early detection of new breast cancer cases and the reduction of the mortality the disease causes. ${ }^{23}$

\section{CONCLUSION}

In Brazil, during the study period, it was verified that women between 40 and 44 years of age presented the largest proportion of mammograms, reaching about $90 \%$ in 2012. In Santa Catarina, the age range from 50 to 54 years presented the highest test coverage $(17.3 \%)$ in 2011.

The incidence rates of MNL of the breast detected by clinical exam (palpation) and imaging increased in Santa Catarina and Brazil during the study period. In Brazil, however, the incidence rates by palpation were higher than by imaging between 2010 and 2012. In the State of Santa Catarina, the detection rates by palpation remained practically unaltered, while the detection rates by imaging increased progressively during the study period. In 2012, the detection rate by imaging was higher than the detection rate by palpation. In 2012, the detection rates by imaging were similar in Santa Catarina and Brazil, corresponding to about $14 \%$.

As regards the incidence rates of cases of MNL of the breast confirmed by means of histopathological tests, in Brazil, high rates were observed in the age range between 40 and 44 years. In Santa Catarina, the highest incidence rates were found in women over 59 years of age during the study period.

In view of the findings, it was observed that screening still remains inferior to the recommendations, that the higher proportional distributions of mammograms per age range would permit a larger number of MNL diagnoses and that the periodical mammogram as from the age of 40 years also contributes to the diagnosis of breast cancer in the age range from 40 to 49 years, in Brazil as well as in Santa Catarina.

It is also concluded that mammogram screening in Brazil and in Santa Catarina needs to approach WHO's recommendations and that the number of MNL cases detected by imaging needs to increase.

As a limitation, it is registered that the data included for 2009, the initial year of SISMAMA, may not totally picture the reality in Brazil and in Santa Catarina.

\section{REFERENCES}

1. Aguillar VLN. Sociedade Brasileira de Mastologia [Internet]. Rastreamento mamográfico em mulheres com idade entre 40 e 49 anos. Rio de Janeiro: SBM; 2012 [cited 2015 Jul 28]. Available from: http:// www.sbmastologia.com.br/artigo/rastreamentomamografico-em-mulheres-com-idade-entre-40-e49-anos-85.htm

2. International Agency for Research on Cancer. Globocan 2012 Breast Cancer: estimated incidence, mortality and prevalence worldwide in 2012 [Internet]. Lion (FR): IARC, 2012; [Internet] [cited 2015 Jun 06]. Available from: http://globocan.iarc. fr/Pages/fact_sheets_cancer.aspx

3. Instituto Nacional do Câncer (BR). Estimativa 2016: incidência do câncer no Brasil. Rio de Janeiro: INCA; 2016.

4. U.S. Preventive Services Task Force [Internet]. Final Update Summary: Breast Cancer: Screening. Rockville (US): USPSTF; 2015 [cited 2015 Jun 06]. Available from: http://www.uspreventiveservicestaskforce. org/Page/Document/UpdateSummaryFinal/breastcancer-screening

5. Roxanne N. USPSTF Updates Its Breast Cancer Screening Recommendations. Medscape Medical News [Internet]. 2015 [cited 2015 Jul 28]. Available from: http://www.medscape.com/viewarticle/843410

6. Gregory KD, Sawaya GF. Updated recommendation for breast cancer screening. Curr Opin Obstet Gynecol. 2010; 22(6):498-505.

7. Ministério da Saúde (BR). Secretaria de Atenção à Saúde. Instituto Nacional de Câncer. Coordenação de Prevenção e Vigilância (CONPREV). Controle do Câncer de Mama: documento de consenso. Rio de Janeiro: INCA; 2004.

8. RosaLM, Radünz V.Survival rates towoman with breast cancer: review. Texto Contexto Enferm. [Internet]. 2012 [cited 2015 Nov 29]; 21(4):980-9. Available from:http://www.scielo.br/scielo.php? script=sci_ arttext\&pid=S0104-07072012000400031\&lng=en

9. Ministério da Saúde (BR). Departamento Informática do Sistema Único de Saúde [página da Internet]. Sistema de Informações do Câncer de Mama. Rio de Janeiro: Ministério da Saúde; 2014 [cited 2014 Mar 18]. Available from: http://w3.datasus.gov.br/siscam/ index.php?area $=0402$

10. Instituto Brasileiro de Geografia e Estatística. Censo Demográfico 2010: características da população e dos domicílios - resultados do universo. Rio de Janeiro: IBGE; 2011.

11. Ministério da Saúde (BR). Instituto Nacional do Câncer. Coordenação Geral de Prevenção e Vigilância. Divisão de Deteç̧ão Precoce e Apoio às Organizações 
de Rede. Ficha técnica de indicadores relativos às ações de controle do câncer de mama. Rio de Janeiro: INCA; 2014.

12. Oliveira EXG, Pinheiro RS, Melo ECP, Carvalho MS. Condicionantes socioeconômicos e geográficos do acesso à mamografia no Brasil, 2003-2008. Ciênc Saúde Coletiva 2011; 16:3649-64.

13. Moreira CB, Bezerra KC, Mendes IC, Santos MCL, Oria MOB, Fernandes AFC. Prevalência de exames momográficos em mulheres brasileiras no período 2009 a 2010. Rev Enferm UERJ. 2013; 21(2):151-5.

14. Schneider IJC, Giehl MWC, Boing AF, d'Orsi E. Rastreamento mamográfico do câncer de mama no Sul do Brasil e fatores associados: estudo de base populacional. Cad Saúde Pública. 2014; 30(9):1987-97.

15. World Health Organization. Early detection. Cancer control: knowledge into action. WHO guide for effective programmes. Module 3. Geneva (CH): World Health Organization; 2007.

16. Biesheuvel C, Weigel S, Heindel W. Mammography screening: evidence, history and current practice in Germany and other European Countries. Breast Care. 2011; 6(2):104-9.

17. Haikel Jr RL, Mauad EC, Silva TB, Matos JSC, Chala LF, Longatho-Filho A, et al. Mammography-based screening program: preliminary results from a first 2-year round in a Brazilian region using mobile and fixed units. BMC Womens Health. 2012 Oct 2; 12:32.

18. De Castro Mattos JS, Mauad EC, Syrjänen K, LongattoFilho A, Haikel RL, Da Costa Vieira RA, et al. The impact of breast cancer screening among younger women in the Barretos Region, Brazil. Anticancer Res [Internet]. 2013 Jun [cited 2015 Jul 28]; 33(6):26515. Available from: http://ar.iiarjournals.org/ content/33/6/2651.long
19. Meissner HI, Klabunde CN, Han PK, Benard NB, Breen $\mathrm{N}$. Breast cancer screening beliefs, recommendations and practices: primary care physicians in the United States. Cancer [Internet]. 2011 [cited 2015 Jul 28]; 117(14):3101-11. Available from: http:/ / onlinelibrary. wiley.com/doi/10.1002/cncr.25873/pdf

20. Sociedade Brasileira de Mastologia. Sociedade Brasileira de Cancerologia. Colégio Brasileiro de Cirurgiões. Colégio Brasileiro de Radiologia. Câncer de mama: prevenção secundária. São Paulo (SP): Associação Médica Brasileira, Agência Nacional de Saúde Complementar; 2011.

21. Urban LABD, Schaefer MB, Duarte DL, Santos RP, Maranhão NMA, Kefalas AL, et al. Recomendações do Colégio Brasileiro de Radiologia e Diagnóstico por Imagem, da Sociedade Brasileira de Mastologia e da Federação Brasileira das Associações de Ginecologia e Obstetrícia para rastreamento do câncer de mama por métodos de imagem. Radiol Bras [Internet]. 2012 [cited 2015 Ago 07]; 45(6):334-9. Available from: http://www.scielo.br/scielo.php?script=sci_ arttext\&pid=S0100-39842012000600009\&lng=en

22. Rosa LM, Radünz V. Women with breast cancer: from symptoms to adjuvant treatment. Texto Contexto Enferm [Internet]. 2013 [cited 2015 Nov 29]; 22(3):713-21. Available from: http://www. scielo.br/scielo.php?script=sci_arttext\&pid=S010407072013000300018\&lng=en

23. Azevedo e Silva G, Bustamante-Teixeira MT, Aquino EML, Tomazelli JG, dos-Santos-Silva I. Acesso à detecção precoce do câncer de mama no Sistema Único de Saúde: uma análise a partir dos dados do Sistema de Informações em Saúde. Cad Saúde Pública [Internet]. 2014 Jul [cited 2016 Mar 11]; 30(7):1537-50. Available from: http:/ / www.scielo.br/scielo.php?script=sci_ arttext\&pid=S0102-311X2014000701537\&lng=en 